\title{
葉緑体母性遺伝の分子機構と性
}

\author{
西村芳樹 1,2 \\ 1 京都大学大学院理学研究科植物分子遺伝学研究室 干606-8502 京都市左京区北白川追分町 \\ 2 JST さきがけ
}

\begin{abstract}
要旨 : ミトコンドリア（mt）や葉緑体（cp）の遺伝子は多くの生物において母親のみから遺伝する（母性遺伝）. これまで母性遺伝は，父母の配偶子（精子・卵子）の大きさが異なり， mt/cpDNA 量に差があることが原因と 考えられてきた。これに対し，䧳雄同形の配偶子で生殖をおこなう単細胞緑藻クラミドモナス (Chlamydomonas reinhardtii）では，接合後 60 分以内に雄の葉緑体（cp）DNAが積極的に分解されることで母性遺伝が引き起こさ れる. 本レビューでは，この雄葉緑体DNAの急激かつ選択的な分解を明らかにしてきた生化学，細胞学，顕微分 子生物学的研究の数々について俯瞰し, さらに母性遺伝の分子機構に迫りつつある遺伝学的な挑戦について述べる.
\end{abstract}

\section{Molecular mechanism of maternal inheritance and sexual differentiation}

\author{
Yoshiki Nishimura ${ }^{1,2}$ \\ 1 Department of Botany, Graduate School of Sciences, Kyoto University, Oiwake-cho, Sakyo-ku, Kyoto 606-8502, Japan \\ 2 PRESTO, JST, 4-1-8 Honcho Kawaguchi, Saitama, Japan \\ Author for correspondence: Yoshiki Nishimura, yoshiki@pmg.bot.kyoto-u.ac.jp
}

Summary: Chloroplast (cp) and mitochondrial (mt) genomes are inherited almost exclusively from one parent in diverse taxa of plants and animals. Uniparental inheritance of $\mathrm{mt} / \mathrm{cp}$ genomes was long thought to be the passive outcome of the fact that eggs contain multiple numbers of organelles whereas the contributions from male gametes are limited. However, the process is likely to be more dynamic because uniparental inheritance occurs in organisms that produce gametes of identical sizes (isogamous). In Chlamydomonas reinhardtii, uniparental inheritance of $\mathrm{cp} /$ $\mathrm{mt}$ genomes is achieved by a series of mating type-controlled events that actively eliminate mating type minus (mt-) cpDNA within 60 min after mating. How Chlamydomonas selectively degrades mt- cpDNA has long fascinated researchers and is the subject of this review.

Key words: ミトコンドリア，母性遺伝，真正粘菌，mtDNA

\begin{abstract}
はじめに
1900 年，ドイツのコレンス，ド・フリース，オースト リアのチェルマックら 3 人の研究者によってほぼ同時期 にメンデルの法則が再発見された。それから9年後の 1909年，コレンスはオシロイバナ (Mirabilis jalapa)の 葉の色に着目し，これがメンデルの法則に従わず，母 親のみから次世代に遺伝すること (母性遺伝)を発見し た。同年, ドイツのバウアはゼラニウムの葉の斑入りが 両親から遺伝すること (両性遺伝) を報告した。その後 の精力的な電子顕微鏡観察によって，この奇妙な遺伝 様式が，葉緑体の異常に由来すると推定された（総説 Hagemann 2010)。葉緑体のDNA（cpDNA）の存在が 証明されたのは，細胞質遺伝の発見から半世紀以上 経た1963年のことである (Sager and Ishida 1963).

一方，ミトコンドリア遺伝の研究は，まずアカパンカ ビや酵母の呼吸欠損変異の非メンデル遺伝の解析とし
\end{abstract}

てはじまった. 1970年から1980年にかけて，アフリカ ツメガエル, ほ乳類 (ロバ), マウス, ショウジョウバエ, さらにヒトなど様々な生物種において次々にミトコンドリ ア $(\mathrm{mt})$ の母性遺伝が報告されてきた．現在では，い くつかの興味深い例外はあるものの, mt/cpDNAの母 性（片親）遺伝はヒ卜を含む多くの真核生物（動物，被 子植物，シダ，コケ，藻類，原生生物等）に共通する 普遍的な現象であることが明らかになっている（Birky 2008, Kuroiwa 2010).

\section{母性遺伝の古典的説明とその問題点}

それでは，ミトコンドリアや葉緑体の母性遺伝は一体 どのようなしくみで起きるのだろうか?一説には，卵と 精子のサイズの違いが重要な役割を果たしていると言 われる，確かに卵は大きく，一個当たり少なくとも $10^{4}$ 〜108コピーのミトコンドリアDNAを含むといわれる. そ 
れに対し，精子は小さく，僅か 100 コピー程を含むに過ぎない. この圧倒的な量差が母性遺伝の 基盤であると言われて来た。確 かにこの考え方は直感的で説得 力があるが反論も多い(AnkelSimons and Cummins 1996). と りわけ，これに対して大きな疑問 符を投げかけたのが，単細胞緑 藻クラミドモナス (Chlamydomonas reinhardtii) における葉緑体母 性遺伝である(総説 Nishimura 2010).

クラミドモナスは，直径わずか $10 \mu \mathrm{m}$ ほどの小さな緑藻である. 1 個のお椀型の葉緑体と，それ を取り囲む網状のミトコンドリアを もち，2本の鞭毛で水中を元気 に泳ぎ回る.クラミドモナスには， 雄 (mating type minus: $m t$-) と雌 (mating type plus: $m t+$ ) の二つの 性があり, 雄雌同形の配偶子で 生殖をおこなう(図 1A). そのた め両親は，子孫に対して等量の cpDNAを寄与する. それにも関 わらず，葉緑体は母親遺伝する (Sager 1954). セガーらは, 放 射線同位体を用いて雌雄の葉緑 体DNAを別々に標識して追跡す ることにより，接合後 24 時間後ま

でに，雄 cpDNAが雌に対して顕著に減少することを示 した (Sager 1972)。そして1982年，黒岩らは，DNA 特異的色素DAPIを用いた蛍光顕微鏡観察により，接 合後わずか 60 分以内に雄の cpDNA- 蛋白質複合体 (核 様体) が完全に消えてしまうことを明らかにした（図 1B， Kuroiwa et al. 1982).

\section{1 細胞から明らかにされた雄葉緑体DNAの積極的な分解}

クラミドモナス接合子での雄葉緑体核様体の消失の 意味について，さらに詳しく調べるために，私たちはま ず葉緑体形質転換法によって外来遺伝子配列 $a a d A$ を 挿入することにより䧳雄の cpDNAを標識した。次に雄
の葉緑体核様体の輝点の有無に基づいて,「光ピンセッ 卜」により接合子を 1 個ずつ捕まえて試験管内に回収した. 光ピンセットとは, 顕微鏡で狙った 1 個の細胞, 細菌, 細胞内小器官を, 高度に集光した赤外線レーザー光 により，生のまま非接触的に捕捉し，動かすことができ る技術である (Ashkin et al., 1987)。回収した1細胞に ついて, 超高感度 PCR 法による解析をおこなった結果, 雄の葉緑体核様体の消失とともに，雄葉緑体DNAが 完全に分解されること，そしてこれこそが，クラミドモナ スの葉緑体母性遺伝の基盤であることが明らかになっ た (図2, Nishimura et al. 1999). 
A

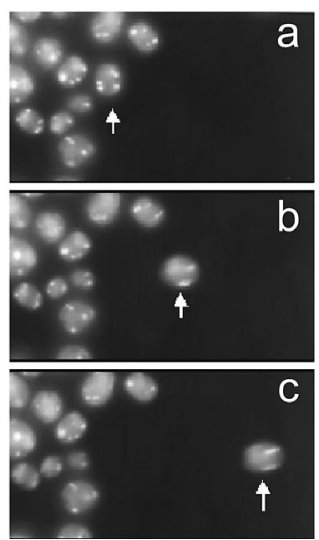

B

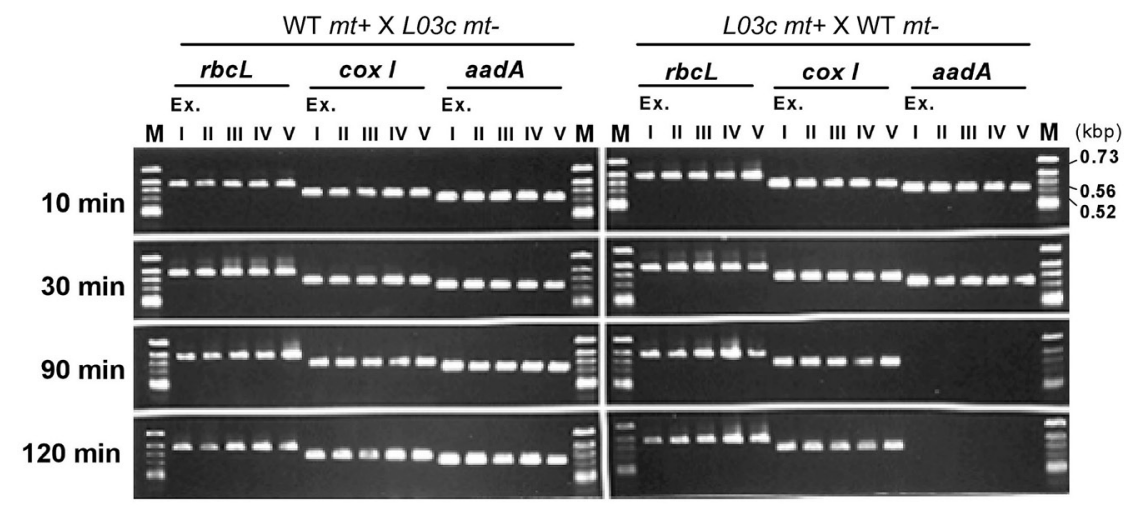

図 2 (A) 光ピンセットによる1クラミドモナス細胞の捕捉, 操作 (矢印)。クラミドモナス細胞はホルムアルデヒド固定後 DAPI染色 し，UV励起光下で光ピンセッ操作した (a-c).（B）1 細胞PCRによる接合子の解析．接合後 $10 \mathrm{~min} ， 30 \mathrm{~min}$ の細胞集団からは 雄葉緑体核様体がある接合子，接合後 $90 \mathrm{~min}, 120 \mathrm{~min}$ の細胞集団からは雄葉緑体核様体がみえない接合子をそれぞれ 1 個

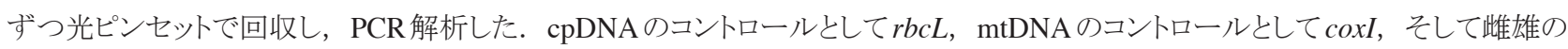
cpDNAの標識として a adAを増幅した。a adA は左パネルでは雌cpDNAに，右パネルでは雄cpDNAに導入した。解析の結果， 雄葉緑体核様体消失とともに, 雄 cpDNAに導入されたa adA は全く増幅されなくなった (西村ら, PNAS 1999より改変).

\section{雄葉緑体DNAが選択的に分解されるし} くみ

雄の葉緑体DNAの分解は, どのよう にして引き起こされるのだろうか. その手 掛かりを得るべく，接合子から雄と雌の 葉緑体をべつべつに回収する方法を模 索した. 試行錯誤の末に, 雌雄の配偶 子の培養条件を調節することで, 雌雄の どちらかの葉緑体のみにデンプンを蓄積 させ，パーコール密度勾配遠心法により 雌雄の葉緑体を選択的に回収出来るよ うになった. 雌雄の葉緑体でヌクレアー ゼ活性を比較したところ，接合後 60 〜 90 分後, 雄の葉緑体で特異的に活性が 高まる $\mathrm{Ca}^{2+}$ 依存性ヌクレアーゼが同定さ れ, 雄の葉緑体DNA 分解の有力な担 い手であると考えられた (Nishimura et al. 2002).

一方, 雌葉緑体DNAの保護機構に ついては,「メチル化制限酵素仮説」が 長らく議論の対象となってきた. 1972年, セガーとレーンは, 雌の葉緑体DNAが 配偶子誘導，および接合子成熟にともなって選択的に メチル化されることを発見した。 この観察にもとづき，雄 の葉緑体DNAを破壊するのは制限酵素であり，雌の
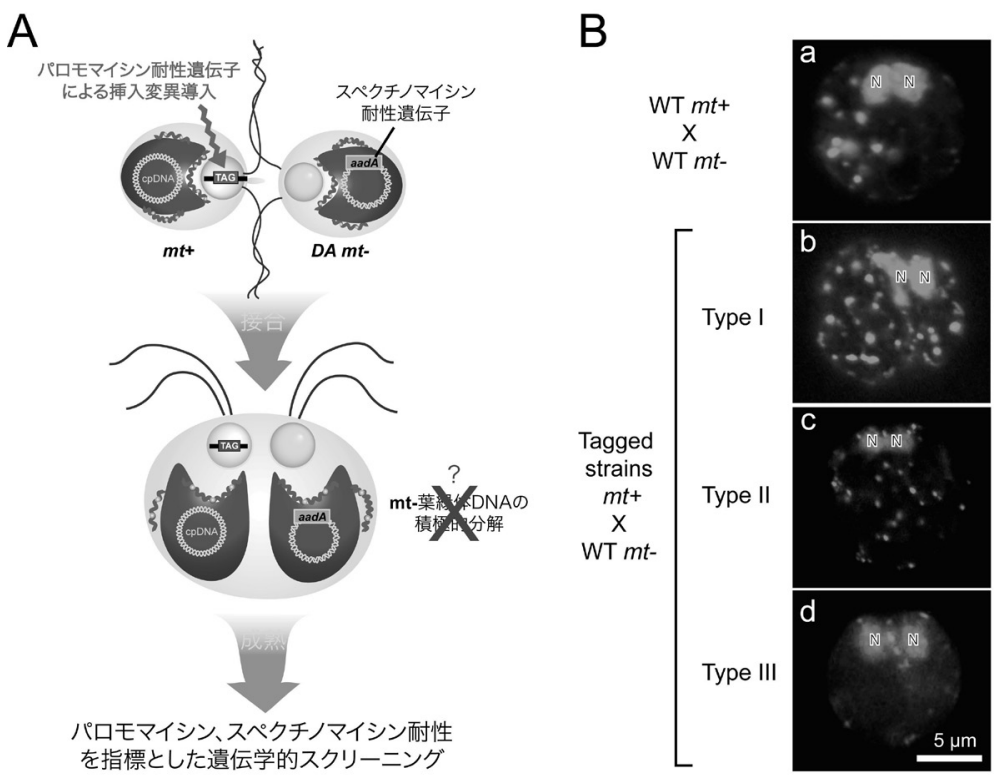

図3(A) クラミドモナスのタギングによる母性遺伝変異体単離の戦略. $m t+$ 株を対象とした扱入変異導入を行ったタギングラインを葉緑体にスペクチノマ イシン而性遺伝子 (aadA)を組み込んだ雄株 (DA $m t$-) と交配させ，子孫にス ペクチノマイシン耐性が遺伝するものをスクリーニングすることにより，母性遺 伝変異体を単離する。 (B) 獲得された変異体をWT $m t$ - と交配させた接合子 (接合 60 分後) をDNA 特異的蛍光色素SYBR Green I染色した蛍光顕微鏡 像 (a-d) . $m t-$ cpDNA が消失する野生型接合子 (a) に対して, 両方残るもの (Type I, b), 両方小さくなるもの (Type II, c), 両方消失するもの (Type III, d) など, 様々な変異体が得られて来ている.

葉緑体DNAはメチル化によって保護されると推測した (Sager and Lane 1972)。しかし他のグループによる葉 緑体DNAの過メチル化変異株や，メチル化阻害剤を 
用いた実験結果は，いずれもその可能性を否定するも のであった (Bolen et al. 1982, Feng and Chiang 1984). 2002 年, 雌配偶子特異的な葉緑体DNAメチル化を担 うらしい葉緑体局在型メチルトランスフェラーゼの遺伝子 が，ついに同定された (Nishiyama et al. 2002)。しかし， その遺伝子を雄で異所的に発現させてみても母性遺伝 の劇的な変化は観察されず（Nishiyama et al. 2004）, 一方でメチル化は雌葉緑体DNAの選択的増幅を促進 させることで母性遺伝様式を保証しているとする仮説も 提唱されている (Umen and Goodenough 2001).

珍しい例として，葉緑体がへテロプラスミックな (1葉 緑体内に複数種のゲノムが混在する) 株を雌株 $(m t+)$ と して交配すると，そのうち一部のみが次世代に遺伝す る (Nishimura et al. 2004)。 その遺伝様式は個々の葉 緑体ゲノムの複製速度に依存していることから，確実な 母性遺伝を保証するためには選択的な分解のみでなく, 複製もまた重要であることが示唆されている (Nishimura and Stern 2010).

\section{母性遺伝変異体の探索}

クラミドモナスでは，ゲノムプロジェクトの進行に伴い, 豊富なゲノム情報を利用する事ができるようになってき た (Merchant et al. 2007). また, 挿入変異導入法 (タ ギング）による大規模な変異体スクリーニングも実現し ている (Matsuo et al. 2008). 我々もまた, 雄の葉緑体 DNAの分解を担う遺伝子を探るべく，母性遺伝変異 体の単離，および接合子特異的遺伝子の逆遺伝学的 解析に取り組んでいる，得られてきた変異体のなかに は，接合子の成熟自体がとまるものや，雌雄の葉緑体 DNAの蛍光が消えるものなど，予想外の表現型を示 す変異体もみつかってきている(西村ら, 論文投稿中). 今後, これらの変異体の解析を通し, 母性遺伝を制御 する遺伝子群を一つ一つ明らかにしていくことで，真核 生物の母性遺伝のしくみに迫れるものと考えている.

\section{真核生物の母性遺伝の理解にむけて}

クラミドモナスから，他の生物の母性遺伝に目を向 けてみる. 1995 年，マウスにおいても雄ミトコンドリア DNAの直接的分解が報告された (Kaneda et al. 1995). 2002 年には, ユビキチン化によって動物の精子ミトコン ドリアの蛋白質分解が促進されている可能性が報告さ れている (Sutovsky et al. 1999)。私たちもまた, 卵生
生殖をおこなうメダカ (Oryzias latipes) をもちいて，精 子の $\mathrm{mt}$ 核様体を可視化して生殖前後の挙動を追跡し てみたところ，mt核様体が受精後 1 時間ほどで消失す る様子が観察された。ささらに 1 匹の精子を $\mathrm{mt}$ 核様体の 有無にもとづいて光ピンセットにより回収して PCR 解析 した結果，雄の $\mathrm{mt}$ 核様体の消失と共に，mtDNAが検 出されなくなり, 脊椎動物においても雄 mtDNA が受精 に伴って積極的に分解されることが示さた (Nishimura et al. 2006) .

高等植物では, DNA 特異的蛍光色素を用いた網 羅的細胞学的研究により, 花粉減数分裂中の, 色素 体及びミトコンドリアDNAの分解及び増幅が，その遺 伝様式を決定する上で重要であることが示されている (Nagata et al. 1999). ここでもまた，母性遺伝は単なる 確率論で説明できるものではなく，厳密な制御下に置 かれている可能性が示唆されている.

母性遺伝が最初に葉緑体で報告されてより，100年 が過ぎた. 雄DNAや蛋白質の積極的分解, 雌DNA の保護と特異的増幅, 様々な仮説が提唱される中, 卵 と精子のサイズ差に基づく確率論的説明は過去のもの となりつつある。その制御遺伝子群，雄葉緑体DNA 選択的分解の詳細な分子機構の解明を通し, 母性遺 伝の真核生物の進化における意義に迫っていきたい.

\section{謝辞}

立教大学, 黒岩常祥先生, 黒岩晴子先生の御指導 に感謝致します，実験にご協力頂いた三角修己 先生 (山口大学), 加藤晃 先生 (奈良先端大学院大学), 福澤秀哉 先生 (京都大学), 神谷律 先生 (東京大 学), 松尾拓哉 先生 (名古屋大学), 内宮博文 先生 (東京大学, 埼玉大学), 鹿内利治 先生 (京都大学) そして技術補佐員の田中瞳 様 (京都大学) に, 心から 御礼申し上げます。本研究はJSTさきがけ，日本学術 振興会 (若手B19770050) による研究助成により遂行さ れました。

\section{引用文献}

Ankel-Simons, F., and Cummins, J. M. (1996) Misconceptions about mitochondria and mammalian fertilization: implications for theories on human evolution. Proc Natl Acad Sci USA 93: 13859-13863.

Ashkin, A., Dziedzic, J. M., and Yamane, T. (1987) Optical trapping and manipulation of single cells using infrared 
laser beams. Nature 330: 769-771.

Birky, C. W., Jr. (2008) Uniparental inheritance of organelle genes. Curr Biol 18: R692-695.

Bolen, P. L., Grant, D. M., Swinton, D., Boynton, J. E., and Gillham, N. W. (1982) Extensive methylation of chloroplast DNA by a nuclear gene mutation does not affect chloroplast gene transmission in Chlamydomonas. Cell 28: 335-343.

Feng, T. Y., and Chiang, K. S. (1984) The persistence of maternal inheritance in Chlamydomonas despite hypomethylation of chloroplast DNA induced by inhibitors. Proc Natl Acad Sci USA 81: 3438-3442.

Hagemann, R. (2010) The foundation of extranuclear inheritance: plastid and mitochondrial genetics. Mol Genet Genomics 283: 199-209.

Kaneda, H., Hayashi, J., Takahama, S., Taya, C., Lindahl, K. F., and Yonekawa, H. (1995) Elimination of paternal mitochondrial DNA in intraspecific crosses during early mouse embryogenesis. Proc Natl Acad Sci USA 92: 45424546.

Kuroiwa, T. (2010) Review of cytological studies on cellular and molecular mechanisms of uniparental (maternal or paternal) inheritance of plastid and mitochondrial genomes induced by active digestion of organelle nuclei (nucleoids). J Plant Res 123: 207-230.

Kuroiwa, T., Kawano, S., Nishibayashi, S., and Sato, C. (1982) Epifluorescent microscopic evidence for maternal inheritance of chloroplast DNA. Nature 298: 481-483.

Matsuo, T., Okamoto, K., Onai, K., Niwa, Y., Shimogawara, K., and Ishiura, M. (2008) A systematic forward genetic analysis identified components of the Chlamydomonas circadian system. Genes Dev 22: 918-930.

Merchant, S. S., Prochnik, S. E., Vallon, O., Harris, E. H., Karpowicz, S. J., Witman, G. B., Terry, A., Salamov, A., Fritz-Laylin, L. K., Marechal-Drouard, L., Marshall, W. F., Qu, L. H., Nelson, D. R., Sanderfoot, A. A., Spalding, M. H., Kapitonov, V. V., Ren, Q., Ferris, P., Lindquist, E., Shapiro, H., Lucas, S. M., Grimwood, J., Schmutz, J., Cardol, P., Cerutti, H., Chanfreau, G., Chen, C. L., Cognat, V., Croft, M. T., Dent, R., Dutcher, S., Fernandez, E., Fukuzawa, H., Gonzalez-Ballester, D., Gonzalez-Halphen, D., Hallmann, A., Hanikenne, M., Hippler, M., Inwood, W., Jabbari, K., Kalanon, M., Kuras, R., Lefebvre, P. A., Lemaire, S. D., Lobanov, A. V., Lohr, M., Manuell, A., Meier, I., Mets, L., Mittag, M., Mittelmeier, T., Moroney, J. V., Moseley, J., Napoli, C., Nedelcu, A. M., Niyogi, K., Novoselov, S. V., Paulsen, I. T., Pazour, G., Purton, S., Ral, J. P., RianoPachon, D. M., Riekhof, W., Rymarquis, L., Schroda, M., Stern, D., Umen, J., Willows, R., Wilson, N., Zimmer, S. L., Allmer, J., Balk, J., Bisova, K., Chen, C. J., Elias, M., Gendler, K., Hauser, C., Lamb, M. R., Ledford, H., Long, J.C., Minagawa, J., Page, M. D., Pan, J., Pootakham, W., Roje, S., Rose, A., Stahlberg, E., Terauchi, A. M., Yang, P., Ball, S., Bowler, C., Dieckmann, C. L., Gladyshev, V. N., Green, P., Jorgensen, R., Mayfield, S., Mueller-Roeber, B., Rajamani, S., Sayre, R. T., Brokstein, P., Dubchak, I., Goodstein, D., Hornick, L., Huang, Y. W., Jhaveri, J., Luo, Y., Martinez, D., Ngau, W. C., Otillar, B., Poliakov, A.,
Porter, A., Szajkowski, L., Werner, G., Zhou, K., Grigoriev, I. V., Rokhsar, D. S., and Grossman, A. R. (2007) The Chlamydomonas genome reveals the evolution of key animal and plant functions. Science 318: 245-250.

Nagata, N., Saito, C., Sakai, A., Kuroiwa, H., and Kuroiwa, T. (1999) The selective increase or decrease of organellar DNA in generative cells just after pollen mitosis one controls cytoplasmic inheritance. Planta 209: 53-65.

Nishimura, Y. (2010) Uniparental inheritance of cpDNA and the genetic control of sexual differentiation in Chlamydomonas reinhardtii. J Plant Res 123: 149-162.

Nishimura, Y., and Stern, D.B. (2010) Differential replication of two chloroplast genome forms in heteroplasmic Chlamydomonas reinhardtii gametes contributes to alternate inheritance patterns. Genetics 185: 1167-1181.

Nishimura, Y., Kikis, E.A., Zimmer, S.L., Komine, Y., and Stern, D.B. (2004). Antisense transcript and RNA processing alterations suppress instability of polyadenylated mRNA in Chlamydomonas chloroplasts. Plant Cell 16: 2849-2869.

Nishimura, Y., Misumi, O., Matsunaga, S., Higashiyama, T., Yokota, A., and Kuroiwa, T. (1999) The active digestion of uniparental chloroplast DNA in a single zygote of Chlamydomonas reinhardtii is revealed by using the optical tweezer. Proc Natl Acad Sci USA 96: 12577-12582.

Nishimura, Y., Misumi, O., Kato, K., Inada, N., Higashiyama, T., Momoyama, Y., and Kuroiwa, T. (2002) An mt(+) gamete-specific nuclease that targets $\mathrm{mt}(-)$ chloroplasts during sexual reproduction in C. reinhardtii. Genes Dev 16: 1116-1128.

Nishimura, Y., Yoshinari, T., Naruse, K., Yamada, T., Sumi, K., Mitani, H., Higashiyama, T., and Kuroiwa, T. (2006) Active digestion of sperm mitochondrial DNA in single living sperm revealed by optical tweezers. Proc Natl Acad Sci USA 103: 1382-1387.

Nishiyama, R., Ito, M., Yamaguchi, Y., Koizumi, N., and Sano, H. (2002) A chloroplast-resident DNA methyltransferase is responsible for hypermethylation of chloroplast genes in Chlamydomonas maternal gametes. Proc Natl Acad Sci USA 99: 5925-5930.

Nishiyama, R., Wada, Y., Mibu, M., Yamaguchi, Y., Shimogawara, K., and Sano, H. (2004) Role of a nonselective de novo DNA methyltransferase in maternal inheritance of chloroplast genes in the green alga, Chlamydomonas reinhardtii. Genetics 168: 809-816.

Sager, R. (1954) Mendelian and Non-Mendelian Inheritance of Streptomycin Resistance in Chlamydomonas reinhardtii. Proc Natl Acad Sci USA 40: 356-363.

Sager, R. (1972) Evolution of preferential transmission mechanisms in cytoplasmic genetic systems. Brookhaven Symp Biol 23: 495-502.

Sager, R., and Ishida, M.R. (1963) Chloroplast DNA in Chlamydomonas. Proc Natl Acad Sci USA 50: 725-730.

Sager, R., and Lane, D. (1972) Molecular basis of maternal inheritance. Proc Natl Acad Sci USA 69: 2410-2413.

Sutovsky, P., Moreno, R.D., Ramalho-Santos, J., Dominko, T., Simerly, C., and Schatten, G. (1999) Ubiquitin tag for 
sperm mitochondria. Nature 402: 371-372.

Umen, J.G., and Goodenough, U.W. (2001) Chloroplast DNA methylation and inheritance in Chlamydomonas. Genes Dev 15: 2585-2597. 